\title{
СТУКТУРНО-СЕМАНТИЧНІ ОСОБЛИВОСТІ ТИПОВОЇ СЛОВОТВІРНОЇ ПАРАДИГМИ ВІДПРИКМЕТНИКОВИХ КОНФІКСАЛЬНИХ ДІЕСЛІВ НА ПОЗНАЧЕННЯ ЗМІНИ ЯКОСТІ ПРЕДМЕТА В УКРАЇНСЬКІЙ МОВІ
}

Кушлик О. П. Стуктурно-семантичні особливості типової словотвірної парадигми відприкметникових конфіксальних дієслів на позначення зміни якості предмета в українській мові.

У статті визначено структуру та встановлено континуум словотвірних значень типової словотвірної парадигми відприкметникових конфіксальних дієслів на позначення зміни якості предмета. 3'ясовано, що мотивовані цими дієсловами деривати належать до трьох словотвірних зон (субстантивної, вербальної й ад'єктивної), у межах кожної виокремлено різну кількість семантичних позицій і виявлено набір словотворчих засобів, що реалізують їх.

Ключові слова: словотвірна парадигма, словотвірна зона, словотвірне значення, словотворчий формант, твірна основа, семантична позиція, інхоативне (есивне, каузативне) значення, структурно-семантичний тип, похідне дієслово, вербатив, девербатив, перфектив.

Кушлик О. П. Структурно-семантические особенности типовой словообразовательной парадигмы отприлагательных конфиксальных глаголов со значением изменения качества предмета в украинском языке.

В статье определена структура и установлен континуум словообразовательных значений типовой словообразовательной парадигмы отприлагательных конфиксальных глаголов со значением изменения качества предмета. Выяснено, что мотиворованные этими глаголами дериваты принадлежат к трём словообразовательным зонам (субстантивной, вербальной и адъективной), в пределах каждой виделено разное количество семантических позиций и обозначен набор словообразовательных средств, которые их реализуют.

Ключевые слова: словообразовательная парадигма, словообразовательная зона, словообразовательное значение, словообразовательный формант, производная основа, семантическая позиция, инхоативное (эссивное, каузативное) значение, структурносемантический тип, производный глагол, вербатив, девербатив, перфектив. 
Kushlyk O. P. Structural and semantic peculiarities of a typical word-building paradigm of adjective-motivated confixal verbs which mean changes in quality of an object in the Ukrainian language.

The article determines structure and distinguishes word-building meanings of a typical word-building paradigm of adjective-motivated confixal verbs which mean changes in quality of an object. It is cleared out that derivatives motivated by these verbs belong to three word-building zones (substantive, verbal and adjectival); within each zone different quantity of semantic shades is underlined and a set of word-building devices realizing them is distinguished.

Key words: word-building paradigm, word-building zone, word-building meaning, word-building formant, derivative stem, semantic seat, inchoative (essive, causative) meaning, structural-semantic type, secondary verb, verbative, deverbative, perfective.

Установлення типової словотвірної парадигми слова тієї чи тієї частиномовної належності, зокрема визначення іï структури та виявлення континууму словотвірних значень, задля того, щоб 3'ясувати його дериваційну спроможність, є одним з основних завдань основоцентричного напрямку розвитку дериватології. В україністиці на основі аналізу словотвірних парадигм, тобто комплексних одиниць, що становлять систему дериватів одного ступеня творення, об'єднаних тотожністю твірної основи $[11$, с. $71 ; 9$, с. 10] i протиставлених словотворчими формантами [4, с. 29], уже досліджено словотвірну можливість прикметників [8], іменників [1; 3; 4; 16]. Не може залишатися поза увагою прихильників цього напряму дієслово як один 3 найскладніших морфологічних класів слів. Розгалужена система граматичних категорій i ̈̈х матеріальних виразників граматичних форм - зумовлює активізацію участі дієслівних основ у семантико-словотвірних трансформаціях.

У зарубіжному мовознавстві відомі спроби створення типології словотвірних парадигм слів цього лексико-граматичного розряду. Словотвірні потенції дієслів у російській мові досліджували О. Земська, Т. Морозова, С. Тихонов, Т. Чиканцева, Т. Яруліна, у польській мові - Р. Гжегорчикова, Г. Ядацька; у словацькій К. Бузашшіова, у болгарській - Ст. Калдиєва-Захарієва, Є. Георгієва, В. Нечаєва. Низку наукових праць присвячено проблемам зіставнотипологічного вивчення дієслівного словотворення двох і більше мов: російської та вірменської (Р. Маначурян), російської та білоруської (А. Лукашанець), російської та литовської (С. Бразаускене), російської та чеської (Т. Ацаркіна), української та польської (Л. Сегін), української та німецької (І. Ступак), української, російської та білоруської (Т. Возний), української, російської та польської (Н. Ярошенко), української, англійської та німецької (А. Пузік). 
В україністиці донедавна проаналізовано дериваційну спроможність дієслів лише деяких лексико-семантичних груп [10; 21]. Спеціального ж комплексного дослідження словотвірного потенціалу вербативів сучасної української мови поки що немає, що і зумовило актуальність розпочатих нами досліджень. Увагу зосереджуємо на похідних дієсловах, зокрема відприкметникового походження. Їх традиційно об'єднують у три структурно-семантичні типи: інхоативи, тобто дієслова зі значенням «набувати ознаки, названої твірним прикметником», каузативи, або дієслова із семантикою «наділяти ознакою, названою твірним прикметником», і есиви, або дієслова зі значенням «виявляти ознаку, названу твірним прикметником» $[22$, c. 5]. У попередньо виконаних нами студіях уже проаналізовано словотвірні можливості лексико-семантичних груп інхоативних $[12 ; 14]$ та есивних $[13 ; 23]$ дієслів.

Об'єктом пропонованої розвідки є відприкметникові каузативні вербативи, зокрема на позначення зміни якості предмета. Вони постають за допомогою суфіксального та конфіксального (префіксально-суфіксального) різновидів морфологічного способу творення. Суфіксальні вершинні дієслова утворюються лише за допомогою суфікса -и-ти, пор.: бруднити, волохатити, в'ялити, дірявити, косматити, кострубачити, кошлатити, кудлатити кучерявити, паскудити, пелехатити, плюгавити, свіжити, хорошити, черствити, чистити тощо. Значно більшу кількість словотворчих засобів використовують для творення конфіксальних (префіксально-суфіксальних) вербативів. До них належать конфікси ви- ... -и-ти, від- ... -и-ти, об- ... -и-ти, о- ... -и-ти, під- ... -и-ти, по.. -и-ти, при- ... -и-ти, у- ... -и-ти, пор.: випорожнити, відновити, обновити, оновити, опростити, підновити, погіршити, покращчти, поновити, прискорити, сповільнити, спорожнити, уповільнити, урівноважити та ін.

Мета пропонованого дослідження - визначити структуру та установити континуум словотвірних значень типової словотвірної парадигми відприкметникових конфіксальних дієслів на позначення зміни якості предмета

Їхню типову словотвірну парадигму складають три зони субстантивна, ад'єктивна i вербальна. Субстантивну зону репрезентовано похідними зі словотвірними значеннями «опредметнена дія», «результат (наслідок) дії», «кількість дії» та «знаряддя (інструмент) дії». Виразником першого значення є суфікс 
-нн- (-я) / -енн-(-я) /-анн-(-я). Цей формант переводить дієслівну основу до іменникової, тобто виконує транспозиційну функцію. При цьому дериват зберігає не лише семантику вихідного слова, а й часто успадковує його граматичну категорію виду $[6$, с. 116; 20, с. 462] (простежуємо тенденцію творення від обох компонентів корелятивної видової пари), пор.: виокремлення / виокремлювання, відновлення / відновлювання, виповнення /виповнювання, випорожнити / випорожнювання / випорожняння, випростання / випростування, доповнення / доповнювання, обновлення / обновлювання / обновляння, оновлення / оновлювання / оновляння, перебільшення / перебільшування, переповнення / переповнювання, підновлення / підновлювання / підновляння, полегшення /полегшіння / полегшування, поновлення / поновлювання / поновляння, прискорення / прискорювання тощо, напр.: Його досвід життєвий дав йому ще дуже небагато, сам він також не думав над обновленням свого життя (Лесь Мартович); ...замість поновлення справедливого, основ співіснування, світ зателтотів щось неримське, мов щзойн підгодований тертол... (Є. Пашковський). Похідний субстантив здебільшого у повному обсязі зберігає семантику твірного слова. Так, вершинне дієслово полегшити/полегшувати виражає значення: 1) робити менш важким, таким, що вимагає менших зусиль, легше виконується, здійснюється і т. ін.; 2) робити менш обтяжливим (долю, становище, життя і т. ін.); 3) зменшувати силу вияву; послаблювати (біль, горе, страждання і т. ін.) || Звільняти від болю, тривоги, неспокою і т. ін.; 4) рідко звільняти від частини вантажу, робити меншим вагою (СУМ, VII, с. 63 ). Усі експліковані лексико-семантичні варіанти транспонуються в похідний іменник зі значенням опредметненої дії, напр.: 1) Для полегшення подальшої обробки металу наклеп усувають шляхом відпалювання (Інтернет-ресурс); 2) Деяке полегшення становища народу супроводжувалося дріб'язковим наглядом, бюрократичною регламентацією життя, жорстокою боротьбою імператорського дому за абсолютне єдиновладдя (Інтернет-ресурс); 3) Для полегшення болю дайте дитині соску або скористайтеся спеціальним гелем (3 часопису); 4) Для полегшення вантажу інженери авіаліній Антонова разом зі шведськими виробниками генератора розробили полегшену раму, що й допомогло вкластися в обмеження $i$ встановити абсолютний ваговий рекорд (Інтернет-ресурс).

Крім цього, варіант -енн-(-я) у деяких випадках $є$ водночас виразником опредметненого стану, який передають деривати 
вербальної зони, що постали за допомогою постфікса -ся (про них докладніше йтиметься далі), пор.: випрямлення (від випрямитися), відновлення (від відновитися), заповнення (від заповнитися), наповнення (від наповнитися), обновлення (від обновитися), зниження (від знизитися), оновлення (від оновитися), переповнення (від переповнитися), підвищення (від підвищчитися), полегшення (від полегшитися), поліпшення (від поліпшитися), пониження (від понизитися), сповільнення (від сповільнитися), спрощцення (від спроститися), уподібнення (від уподібнитися) тощо, напр.: Було щуе багато розрізнених повідомлень про лікування голодом, про феноменальне оздоровлення, оновлення, омолодження організму та його функиій... (О. Бердник); ...слід, мабуть, обмежстися ... портретом $і$ через нього передати все те, щзо в мені колобродить, розпач, надію, виснаження й переповнення (В. Діброва). Значно рідше експлікувати опредметнений стан можуть основи дієслів недоконаного виду. Виразником семантики в них постає суфіксінваріант -нн-(-я), пор.: відновлювання (від відновлюватися), заповнювання (від заповнюватися), зниюсування (від знижуватися), оновлювання (від оновлюватися), підновлювання (від підновлюватися), поліпшування (від поліпшуватися), прискорювання (від прискорюватися), пришвидиування (від пришвидиуватися) тощо. У таких похідних одиницях часто спостережено послаблення характеристики тривання в часі, що зумовлює тяжіння до абстрактності позначуваного, напр.: Зворотний зв'язок із замовниками та іниими зацікавленими сторонами, аудити та критичне аналізування системи управління якістю можна також використовувати для визначення можливостей поліпиування (3 посіб.); Одні вчені й практики розглядають моніторинг як засіб удосконалювання системи інформаційного забезпечення управління освітою, інші - як підвищуення ефективності стратегічного планування розвитку середньої й вищуої професійної освіти (I. Аннєнкова).

Деякі девербативи із суфіксом -енн-(-я), співвідносні 3 дієсловами доконаного виду, крім значення опредметненої дії, набувають додаткового, предметного значення, зокрема: 1) результату, наслідку дії (стану), пор.: відновлення, обновлення, оновлення, полегшення, поліпшення, поновлення, ускладнення, утруднення тощо, напр.: Навколишній світ вони [двійко дітей] бачили просто, без усіляких ускладнень (Ю. Коваль); Проте йти із гарбузом 
було неможливо, я відтягував своє приниження (Ю. Коваль); 2) суб'єкта дії, пор.: доповнення, поповнення, напр.: Жона - помічник, однодумецьь, друга половина твого єства, твоє доповнення, спільник у всіх твоїх замірах, сила, щзо стає на твій захист (П. Загребельний); Перекидаючися жартами, пасажирське поповнення зручно вмощується на своїх клунках (Ю. Коваль); 3) об'єкта дії, пор.: поповнення, напр.: - Агов, Василино, приймай поповнення! Дід Яким тпрукає на вгодованих коней, крекчучи зсаджує з воза важкий бідон (Ю. Коваль). У такому разі є всі підстави вважати, що суфікс -енн-(-я) виражає транспозиційно-мутаційне значення.

Уживання субстантивів на -нн-(-я) / -енн-(-я), мотивованих відприкметниковими каузативними дієсловами зі значенням зміни якості предмета, $€$ певною мірою обмеженим. Їх головно використовують у науково-технічній та фінансово-економічній сферах - на позначення тих чи тих процесів. Поряд 3 називанням відповідних операцій, супроводжуваних якісними змінами об'єкта, виникає необхідність визначити кількісні показники (виміри) виконаного процесу. Тому деякі деривати 3 формантом -енн-(-я) можуть експлікувати водночас процес i величину, яка кількісно характеризує цей процес (або стан). Таку модифікацію загального процесуального значення досліджуваних термінів називають «кількістю дії» [20, с. 461]. Щоб розмежувати назви процесу (чи стану) і величини, у другому випадку до аналізованих субстантивів додають іменник 3 кількісною семантикою на зразок коефіuієнт, величина, кількість, градієнт, показник, рівень, кут, квадрат, куб [20, с. 461], пор.: відновлення - коефіцієнт (показник) відновлення, випорожнення - коефіцієнт випорожнення, оновлення - коефіцієнт оновлення, опорожнення - коефіцієнт опорожнення, перебільшення коефіцієнт перебільшення, перевищення - показник (рівень) перевищення, підвищення - коефіцієнт підвищення, покращення показники покращення, поліпшення - коефіцієнт поліпшення, поновлення - коефіцієнт (показник) поновлення, прискорення коефіцієнт (градієнт) прискорення, сповільнення - величина сповільнення, уповільнення - коефіцієнт уповільнення, урівноваження - коефіиієнт урівноваження тощо, напр.: Коефічієнт оновлення основних засобів показує, яку частину від наявних на кінець звітного періоду основних засобів становлять нові основні засоби (3 посіб.); Величина сповільнення при гальмуванні є основним критерісм, який визначає ефективність гальмування (3 посіб.); Супутник GOCE 
запущено у 2009 р. на низькій (260 км) орбіті, на його борту встановлено електростатичний градієнтометр для вимірювання градієнтів прискорення вільного падіння (Ю. Лук'янченко). Значно рідше деривати на -нн-(-я) / -енн-(-я), мотивовані діссловами аналізованої лексико-семантичної групи, номінують ті чи ті поняття в інших сферах науки чи техніки, зокрема: 1) лінгвістиці, пор.: уподібнення, опрощення, спрощення, напр.: Умовою опрощення та інших історичних змін може бути зниження чи втрата продуктивності словотворчого суфікса (Т. Гаврилова); 2) медицині, пор.: випорожнення, ускладнення, утруднення, напр.: Мені знову довелося взяти довідку про те, що мене звалив з ніг грип. 3 ускладненням. Температура 39,6 за Цельсієм (С. Степа); 3) юриспруденції, пор.: поновлення, перевищення, відновлення, напр.: Перевищення влади або службових повноважень - злочин у сфері службової діяльності (3 енциклоп. юрид. слов.); Потреба відновлення судового слідства базується на положеннях КПК України (3 енциклоп. юрид. слов.).

Ще одним засобом вираження значення опредметненої дії у словотвірних парадигмах деяких відприкметникових каузативних конфіксальних дієслів слугує нульовий суфікс. Загалом нульсуфіксальні деривати в українській мові представлено двома моделями: 1) ДО + -Ø-; 2) ДО + -Ø-(-а). Девербативи, утворені за другою моделлю, абсолютно переважають, пор.: віднова, обнова, онова, переповня, полегша, понова, напр.: Несвизький багато говорив нам про віднову держави святого Володимира, - закінчив Судислав, i ми зрозуміли, щчо така держава не постане без волі-свободи народу (Юліан Опільський); Саме музична онова театрального твору додає n'єсі Бабеля романтичної інтонації (Інтернет-ресурс). Характерно, що у віддієслівних іменників 3 нульовим суфіксом, на відміну від іменників на -нн-(-я), утворених від дієслів недоконаного виду, дуже ослаблена процесуальність вираженого ними значення. Це своєю чергою зумовлює здатність їх більшою мірою виражати результативне значення $[7$, с. $11 ; 18$, с. 213], розвиток якого іноді зростає настільки, що часто витісняє основне словотвірне значення «опредметнена дія (стан)». Зокрема, дериват обнова позначає «нова, щойно придбана, пошита, подарована і т. ін. річ (про одяг, взуття)» (СУМ, V, с. 546), напр.: Синенькі, вишиті червоним і жовтим спереду, вони [черевички] були такі гарні, такі новенькі, так приємно пахли обновою, щзо, здавалося, оновили всю їхню квартиру (Б. Харчук); дериват переповня 
- «надмір, надлишок» (ВТС, с. 923), напр.: Писати мене змушує переповня інформацї в голові (Інтернет-ресурс); субстантив полегша - «полегкість» (СУМ, VII, с. 63), напр.: Билися в ньому [Осмомислові] ... два соколи: один сокіл білий, а другий-чорний. Котрийсь з соколів означав полегшу (Р. Федорів).

Трапляється, що той же дериват може вживатися в кількох сферах людської діяльності, від чого залежить зміна семантики позначуваного. Наприклад, дериват понова у бджільництві позначає «утворена бджолами нова вощина у вулику» (ВТС, с. 1048), напр.: Вибілений віск $i$ воскова понова зазвичай не пахнуть (3 посіб.); у мисливстві - «слід звіра на свіжому снігу» (ВТС, с. 1048), напр.: I чекали моменту, щоб була сприятлива для полювання погода: аби випав свіжий сніг (понова) $і$ можна було по слідах вовків піти (Інтернет-ресурс).

Іншу групу похідних, системно репрезентованих у субстантивній зоні, становлять деривати із суфіксом -ач. Цей засіб $є$ поліфункційним, оскільки у словотвірних парадигмах більшості дієслів виражає водночас словотвірні значення «суб'єкт (виконавець) дії» та «інструмент (знаряддя) дії», пор.: Наповнювач балонів 4-го розряду призначається на посаду та звільняється з посади наказом по організації (nідприємству/організащіi) (3 посадової інструкціі) і Будьяка пластмаса складається з двох основних компонентів синтетичної смоли і наповнювача (3 посіб.). Первинним мовознавці вважають перше значення, а відтак друге виникло на базі первинного i спричинило явище суфіксальної омонімії [15, с. 81]. Характерно, що цей словотворчий засіб поєднується 3 основою дієслівних форм недоконаного виду.

Деривати на позначення суб'єкта (виконавця) дії, утворені за допомогою суфікса -ач, постають від дієслів відновлювати, доповнювати, наповнювати, поліпшувати, удосконалювати та ін. пор.: відновлювач, доповнювач, наповнювач, поліпшувач, удосконалювач, напр.: Народ - творецьь $i$ вічний, невтомний удосконалювач своєї мови (Народна творчість). Іноді у межах однієї словотвірної парадигми виразником того ж словотвірного значення може слугувати інший словотворчий засіб, який, 3 одного боку, зумовлює творення дублета (чи дублетів), а з другого - дає підстави для визначення глибини словотвірної парадигми, пор.: відновлювач (суфікс -ач) - відновник (суфікс -ник) - відновитель (суфікс -тель), напр.: Бути відновлювачем традицій украӥнського народу - 
обов'язок кожного, кому дорога його вітчизна. Відновником Кочубеївської давнини $\epsilon$ почесний громадянин Диканщини, благодійник, меценат Юрій Кімінець... (Інтернет-ресурс); Відновителем старостату в Чигирині ... став син великого коронного гетьмана Станіслав Ян Яблоновський (1669-1731 рр.) (Д. Вирський).

Використання суфікса -ач для творення девербативів зі словотвірним значенням «інструмент (знаряддя) дії» $\epsilon$ особливо продуктивним. На думку багатьох мовознавців, цей словотворчий засіб відзначається найвищим ступенем реалізації семантикосинтаксичної інструментальної функції [2, с. 79; 18, с. 82]. Водночас приєднання його до префіксальної мотивувальної основи змінює ступінь абстрактності дії у напрямку до іiі конкретизації: унаслідок творення постає дериват на позначення предмета (знаряддя), призначеного для виконання дії у конкретному виробничому процесі, а не просто дії, як це відображено в семантиці безпрефіксних дієслів [2, с. 80]. Очевидно, з огляду на те формант -ач, за спостереженням В. Пілецького, є активним засобом творення більшості українських фізичних термінів на позначення предметних понять (назв приладів, установок та їхніх складників, ламп) [19, с. 67]. Цю тенденцію простежуємо i на досліджуваному матеріалі, оскільки лише за допомогою нього постають похідні на позначення інструмента (знаряддя) дії, пор.: доповнювач, заповнювач, наповнювач, оновлювач, поліпшувач, поновлювач, полегшувач, прискорювач, пришвидиувач, сповільнювач, уповільнювач, ускладнювач тощо. Словотвірне значення «інструмент (знаряддя) дії» реалізується двома семантичними варіантами: 1) речовина (засіб) дії i 2 ) пристрій (апарат), який використовують для виконання дії. Більшість похідних виражають перший варіант значення, пор.: доповнювач, заповнювач, наповнювач, оновлювач, поліпшувач, поновлювач, прискорювач, полегшувач, ускладнювач, напр.: Головним споживачем сажі $\epsilon$ гумова промисловість, де сажа використовується як заповнювач, який надає гумі високої міцності та еластичності (Інтернет-ресурс). Лише девербатив відокремлювач виражає другий варіант, напр.: Відокремлювач пари вторинного скипання являє собою посудину, щио дозволяе отримати пар низького тиску від перегрітої води (конденсату). Чотири деривати прискорювач, пришвидшувач, сповільнювач, уповільнювач водночас можуть експлікувати обидва значення. Розрізнення того чи того семантичного варіанта 
відбувається в контексті, пор.: Детектор теплових нейтронів можна перетворити на детектор цвидких, оточивщи його царом сповільнювача (засіб) нейтронів, тобто речовиною з великим вмістом водню (3 енциклоп.) і Вагонний сповільнювач (пристрій) - иче пристрій для регулювання швидкості руху вагонів при маневрових роботах (3 енциклоп.).

Вербальну зону формують похідні, що постали за допомогою постфікса -ся. Формант -ся в сучасній українській мові виконує дві функції: словозмінну, тобто служить засобом вираження пасивного значення у предикатах стану, та словотвірну, тобто вживається для утворення дієслів 3 новим лексичним значенням. Відприкметникові дієслова, у яких формант -ся $є$ засобом вираження пасивного стану, 3 огляду на належність граматичної категорії до словозмінних не впливають на дериваційний потенціал вершинних дієслів, тому перебувають поза межами словотвірної парадигми.

Загальне значення, яке властиве усім дієслівним похідним зі словотвірною, або, за Р. Михайлик, словотвірно-граматичною функцією афікса -ся, - це «зосередженість, замкнутість дії на суб'єктові, що виступає носієм предикатної ознаки» [17, с. 8]. А відтак внаслідок приєднання постфікса -ся до дієслів зі словотвірним значенням «наділяти ознакою, названою твірною основою» постає дериват зі словотвірним значенням «набувати ознаки, названої твірною основою» (або «ставати таким, як визначено твірною основою»). Відбувається перехід похідної одиниці зі структурносемантичного типу каузативних дієслів до структурно-семантичного типу інхоативних, пор.: виокремитися, відокремитися, відновитися, випорожснитися, доповнитися, заповнитися, наповнитися, обновитися, оновитися, переповнитися, підновитися, погіршитися, поліпшитися, поновитися, відновитися, прискоритися, пришвидчитися, сповільнитися, сповнитися, спорожнитися, увиразнитися, уповільнитися, уподібнитися, ускладнитися, удосконалитися, утруднитися та ін., напр.: Я знову квапливо пішов вулищею, прислухаючись до Мільхових кроків позаду, ритм яких то несподівано сповільнювався, то так само раптово прискорювався, ніби намагався наздогнати мене (В. Дрозд); Наступич тільки тепер зрозумів, як все ускладнилось... (О. Лупій).

Ад'єктивну зону репрезентовано дериватами із суфіксом -льн(-ий), який приєднується до основи корелята недоконаного виду. Одна группа віддієслівних прикметників становлять «стислі, сконденсовані 
одиниці, сформовані на основі конструкцій 3 відношенням мети» [2, с. 149], а отже, виражають словотвірне значення «ознака за дією предмета, який призначений для ii виконання», пор.: відокремлювальний, відновлювальний, доповнювальний, заповнювальний, наповнювальний, оновлювальний, покращувальний, полегшувальний, поновлювальний, прискорювальний, пришвидиувальний, напр.: Прискорювальний насос призначений для збільшення подачі палива в зону дифузоракарбюратора $i$ забезпечує збагачення горючої сумімі (Інтернет-ресурс). Інші девербативи виражають словотвірне значення «вияв ознаки, яка стосується виконуваної дії», пор.: відновлювальний, поповнювальний, сповільнювальний, напр.: Фахівцями доведено, щзо відновлювальний масаж після інсульту ефективно реабілітує пошкоджені тканини, м'язи і весь організм в иілому (Інтернет-ресурс). Деякі $з$ дериватів залежно від контексту можуть експлікувати обидва цих значення, пор.: наповнювальний, поновлювальний, напр.: Проведення комплексних заходів із ресурсо- та енергозбереження дасть можливість ... створити умови для використання етанолу не тільки в харчовій промисловості, а й $y$ інших галузях як поновлювальної органічної сировини та біопалива (Р. Кириленко) i До групи частково поновлювальних природних ресурсів належать торф, самосадні солі, трунти, ресурси деревини, темпи поновлення яких значно відстають від темпів експлуатації. (3 енциклоп.).

У наведених прикметниках посилюється «дієслівне значення стану у бік постійної ознаки предмета» [5, с. 17]. Саме така специфіка ад'єктива визначає його здатність поповнювати склад відповідних термінологічних одиниць. Цей процес надзвичайно активізується в сучасному термінотворенні, чим зумовлено функціонування низки похідних одиниць, ще не засвідчених усіма лексикографічними джерелами. Наприклад, лише у Великому тлумачному словнику української мови (за ред. В. Бусела) значаться прикметники доповнювальний (ВТС, с. 319), заповнювальний (ВТС, с. 414), наповнювальний (ВТС, с. 730), покращувальний (ВТС, с. 1028), поповнювальний (ВТС, с.1059), сповільнювальний (ВТС, с. 1371).

Отже, типову словотвірну парадигму відприкметникових конфіксальних (префіксально-суфіксальних) дієслів на позначення зміни якості предмета формують послідовно три словотвірні зони. Кожна 3 них репрезентує деривати 3 характерними семантичними позиціями: у субстантивній зоні - «опредметнена дія», «кількість дії», «результат (наслідок) дії» та «знаряддя (інструмент) дії», в 
ад'єктивній зоні - «вияв ознаки за дією предмета, який призначений для іiі виконання», «вияв ознаки, яка стосується виконуваної дії», у вербальній - «набувати ознаки, названою твірною основою». Загалом дериваційна спроможність конфіксальних (префіксальносуфіксальних) відприкметникових каузативних дієслів 3 огляду на їхню семантичну різноплановість (заповнення трьох словотвірних зон), потенційну здатність до терміноутворення $\epsilon$ певною мірою системною, передбачуваною, але обмеженою у вираженні семантичних позицій.

\section{Література}

1. Бачкур Р. О. Структура словотвірних парадигм українських назв тварин та рослин : автореф. дис. ... канд. філол. наук : спец. 10.02.01 «Українська мова»/ Р. О. Бачкур. - Івано-Франківськ, 2004. - 20 с.

2. Безпояско О. К. Суфікси семантичної предметності / О. К. Безпояско, К. Г. Городенська // Морфеміка української мови. - К. : Наук. думка, 1987. - С. 26-90.

3. Беркещук I. С. Дериваційний потенціал іменників у сучасній українській мові : автореф. дис. ... канд. філол. наук : спец. 10.02.01 «Українська мова» / І. С. Беркещук. - Івано-Франківськ, 2007. - 20 с.

4. Валюх 3. О. Словотвірна парадигматика іменника в українській мові : [монографія] / Валюх Зоя Орестівна. - Київ - Полтава : АСМI, 2005. - 356 с.

5. Вихованець I. Р. Частини мови в семантико-граматичному аспекті / I. Р. Вихованець. - К. : Наук. думка, 1988. - 256 с.

6. Вихованець I. Р. Теоретична морфологія української мови / Іван Вихованець, Катерина Городенська ; ред. І. Р. Вихованець. - К. : Універ. вид-во «Пульсари», 2004. -398 c.

7. Городенська К. Г. Проблема словотвірної ідентичності в українській термінології / К. Г. Городенська // Українська термінологія і сучасність. - К., 1998. Вип. 4. - С. 10-13.

8. Грещук В. Український відприкметниковий словотвір / Василь Грещук. Івано-Франківськ : Плай, 1995. - 208 с.

9. Грещук В. Розділ І. Теоретичні засади основоцентричної дериватології / В. В. Грещук, Р. О. Бачкур та ін. // Нариси з основоцентричної дериватології / за ред. Василя Грещука. - Івано-Франківськ : Місто НВ, 2007. - С. 6-38.

10. Джочка І. Ф. Дериваційний потенціал дієслів конкретної фізичної дії 3 семантикою створення об'єкта : автореф. дис. ... канд. філол. наук : спец. 10.02.01 «Українська мова» / І. Ф. Джочка. - Івано-Франківськ, 2003. - 20 с.

11.Земская Е. А. О парадигматических отношениях в словообразовании / Е. А. Земская // Русский язык : Вопросы его истории и современного состояния. Виноградовские чтения I - VIII. - М. : Наука, 1978. - С. 63-77.

12. Кушлик О. П. Специфіка структури та семантики словотвірних парадигм відприкметникових інхоативних дієслів / Оксана Кушлик // Українська мова. - К., 2012. - № 4. - С. 56-67.

13. Кушлик О. П. Словотвірні параметри есивних дієслів зі значенням фізичного стану суб'єкта / О. П. Кушлик // Науковий вісник Чернівецького національного університету імені Юрія Федьковича : зб. наук. праць / наук. ред. Бунчук Б. І. Серія : 
Слов’янська філологія. - Чернівці : Чернівецький нац. ун-т, 2012. - Вип. 648-649. C. 288-291.

14. Кушлик О. П. Параметри словотвірної парадигми відприкметникових інхоативних суфіксальних дієслів зі значенням психічного стану суб'єкта в українській мові / О. П. Кушлик // Лінгвістичні дослідження : зб. наук. праць Харківського національного педагогічного університету імені Г. С. Сковороди. Харків, 2013. - Вип. 36. - С. 93-102.

15. Ландер М. А. Взаємодія словотворчих засобів із семантико-синтаксичною функцією інструменталя / М. А. Ландер // Новітня філологія : журнал. - Миколаїв : Вид-во МДГУ ім. Петра Могили, 2005. - № 3 (23). - С. 77-92.

16. Микитин О. Д. Структурно-семантична типологія словотвірних парадигм іменників у сучасній українській мові : автореф. дис. ... канд. філол. наук : спец. 10.02.01 «Українська мова» / О. Д. Микитин. - Івано-Франківськ, 1998. - 20 с.

17. Михайлик Р. П. Семантико-граматична структура дієслів на -ся в сучасній українській мові : автореф. дис. ... канд. філол. наук : спец. 10.02.01 «Українська мова» / Р. П. Михайлик. - К., 1995. - 16 с.

18. Олексенко В. П. Словотвірні категорії іменника : [монографія] / В. П. Олексенко. - Херсон : Айлант, 2005. - 336 с.

19. Пілецький В. І.До типології словотвірної структури українських фізичних термінів / В. І. Пілецький // Мовознавство. - 1991. - № 6. - С. 66-68.

20. Пілецький В. Назви процесових понять у науково-технічній термінології / Володимир Пілецький //Актуальні проблеми українського словотвору / за ред. В. Грещука. - Івано-Франківськ: Плай, 2002. - С. 459-469.

21. Пославська Н. М. Структура і семантика словотвірних парадигм дієслів із семою руйнування об'єкта : автореф. дис. ... канд. філол. наук : спец. 10.02.01 «Українська мова» / Н. М. Пославська. - Івано-Франківськ, 2006. - 20 с.

22. Сорочан О. В. Лексико-семантичні групи відприкметникових дієслів (семантичний та функціональний аспекти) : автореф. дис. ... канд. філол. наук : спец. 10.02.01 «Українська мова» / О. В. Сорочан. - К., 2005. - 18 с.

23. Kushlyk Oksana. Derivation potential of motivated by adjectives verbs of mental state of the subject in the Ukrainian language / Oksana Kushlyk // Management and Education. Humanities and Social Sciences. Academic Journal. University «Prof. Dr. Assen Zlatarov», Burgas Vol. IX (4) 2013. - C. 71 - 78.

\section{Умовні скорочення}

1. ВТС - Великий тлумачний словник української мови / уклад. і голов. ред. В. Т. Бусел. - К. ; Ірпінь : ВТФ «Перун», 2009. - 1736 с.

2. СУМ-Словник української мови в 11-ти тт. - К. : Наук. думка, 1970. - 1980. 